\section{Safe Niños y Fresh Eyes Cuba: Mariana Amatullo y el diseño de innovación social}

SAFE NIÑOS AND FRESH EYES CUBA:

MARIANA AMATULLO AND DESIGN FOR SOCIAL INNOVATION

CATALINA MANSILLA

Pontificia Universidad Católica de Chile
Santiago, Chile _ clmansil (uuc.cl

XIMENA ULIBARRI

Pontificia Universidad Católica de chile
Santiago, chile mul ibarlacecel

RENATO BERNASCONI

Pontificia Universidad Católica de Chile
Santiago, Chile_bbernasrauc.cl
En este artículo se presentan dos proyectos excepcionales que dan cuenta de la capacidad de transformación social del diseño, Safe Niños y Fresh Eyes Cuba, ambos indisolublemente ligados a la filosofía de Designmatters -el departamento del ArtCenter College of Design en Pasadena dedicado a la formación y desarrollo de proyectos en diseño de innovación social - y a la figura de su cofundadora y vicepresidenta, Mariana Amatullo.

In this article we present two exceptional projects that tell about design's capacity for social transformation, Safe Niños and Fresh Eyes Cuba, both inextricably related to the philosophy of Designmatters - the department at ArtCenter College of Design dedicated to the education and develooment of design projects on social innovationand of the figure of its co-founder and vice president, Mariana Amatullo.

Mariana Amatullo, una de las figuras más emblemáticas del diseño sociales, la hora de trazar vínculos entre dise y política Su trabajo es consecuencia de su visión sobre el rol del diseño y el potencial del diseñador como agente de transformación social, concepció que se vio enriquecida con la reflexión teórica y crítica de su tesis doctoral, titulada "Diseno de actitude innovación disen", curpo detas at a har refer, conceptuales de los proyectos que describiremos en este artículo.

Debido a la relevancia que Designmatters asigna a los métodos procedimientos, dicha descripción se centrará en el proceso de generación de las soluciones implementadas, más que Mariana Amatullo, one of the most emblematic figures in socially-comm design, is an unavoidabale referent politics. Her work is a result of her visio on the role of design and the potentiat. of the designer as agent for social transformation, a concept that has been enriched with the theoretical and critical reflection of her doctoral thesis, entitled Design Attitude and Social Innovation: Empirical Studies of the Return on Defign to a whedy or work that we shall antecedents of the projects desceptual in this article. Given the importance that Designmatters assigns to methods and procedures, this description will be centred on the generation process of the solutions implemented, rather than on en las características de estas. their characteristics.
1

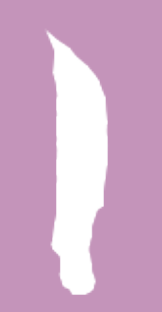

11

D

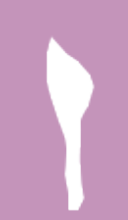

171 


\section{DESIGN ATTITUD}

Design Attitude, el concepto clave ue impulsa el trabajo de Amatullo, Según su definición original, elaborad por Richard Boland y Fred Collopy -autores del libro Managing as designing-, corresponde a las expectativas y orientaciones que u t) destacando las capacidades del diseñador como un conjunto distinto de heurísticas que se desvían de las aptitudes más lineales para la toma de decisiones de los gerentes» (como se citó en Amatulllo, 2015, pág. 15). Para Boland y Collopy, Design Attitude es una preocupación fundamental por

y darse cuenta de presunciones que se han vuelto invisibles y ofrecer nuevas visiones (como se citó en Amatullo. 2015).

Design Attitude, un concepto más holístico que el modelo de resolución de problemas denominado Design hinking, está fundado en la observación de la actitud del diseñador durante el elástico, a partir del que surgen las soluciones definitivas (M. Amatullo comunicación personal, 17 de enero, 2017). Bolan y Collopy proponen el cultivo de este estado de flexibilidad como un momento crucial para la creación y la innovación; asi, Design Attitude no centiva a llegar a soluciones definitivas fluidez, lo que constituye una oportunida para generar conceptos más definidos comunicación personal, 17 de enero, 2017). En este sentido, ambos autores llaman a los diseñadores a involucrarse en procesos, organizaciones, productos y servicios que puedan aportar nuevos valores a la sociedad, tal como apunta Amatulto en su trabajo doctoral (2015). La diseñadora identifica una segunda eferencia importante en el desarrollo de por Kamil Michlewski, quien ha

extendido la conceptualización de los autores precedentes, destacando que el concepto Design Attitude puede ser considerado como un set de herramientas y epistemologías para el crecimiento del el valor de la propuesta de Michlewsilo, 作 original definition, elaborated by Richard categorias principales de Design Boland and Fred Cotlopy-ath ors of the Attitude:1) "Consolidar significados book Managing as Designing - it refers multidimensionales"; 2) "crear, dar vida", to the "expectations and orientations one brings to a design project' (2004: 9), hightighting designers' capabltiles as a

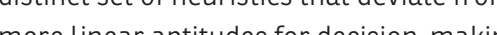
of managers" (as quoted in Amatullo, 2015, p. 15). Per Boland and Collopy Design Attitude is a fundamental concern to invent new alternatives, to question an invisible and to offer new visions (as quoted in Amatullo, 2015).

Design Attitude, a concept that is more holistic than the problem solving model catled Design Thinking, is based attitude during the creative process characterized by a state of openness fluidity, very elastic, from which definitive solutions emerge (M. Amatullo, person communication, January 17, 2017). Bolan and Collopy propose cultivating this state of flexibility as a crucial moment in creation and innovation; thus, Design Attitude does not push reman in this state of furty, butich an opportunity to generate more defin concepts or a definitive solution

M. Amatullo, personal communication, January 17, 2017). In this sense, both authors are summoning designers to get involved in processes, organizations, products, and services that may provide new values to society, just as Amatulo points out in her doctorat work (2015). The designer identifies a second of this concept: the in the development by Kamil Michlewski, who has extended the conceptualization of the preceding authors, underlining that the concept Design Attitude may be thought of as a of tools and epistemologies for the grow

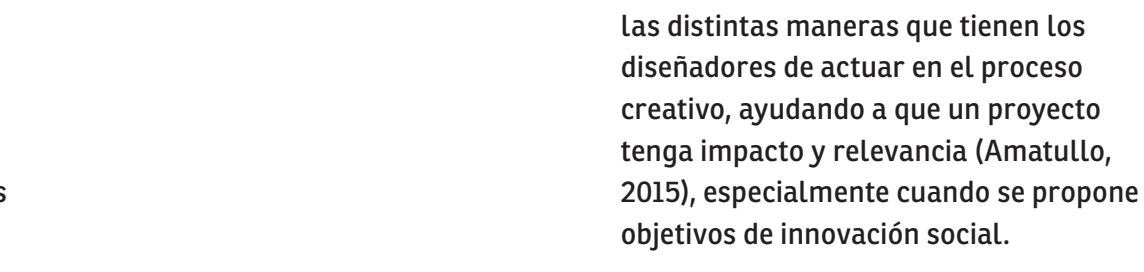

abierto"; 4) "adoptar la empatía personal

y comercial": y 5) "involucrarse con una estética poli-sensorial" (como se citó en Amatullo, 2015, páa. 164). conceptualización de Design Attitude Buchanan, quien to define como las habilidades y capacidades del diseñador, enfocando su rol hacia la figura de un «explorador cultural» (como se cito en defino, liberal de la cultura tecnológica, que se práctica profesional [y] que también provee una amplia perspectiva intelectual sobre el mundo que el ser humano ha construido
(como se citó en Amatullo, 2015, pág. (como se citó en Amatullo, 2015, pág. ta perspectiva de Buchanan ofrece una del Design Thinking, más cercanal pensamiento filośfico de autores como Reshard Mckeon y John Dewey.
Rever

A partir de este recorrido teórico, Amatullo llevó el concepto Design Attitude al ámbito de la innovación seis dimensiones clave, adaptadas de categorías propuestas por Michlewski en 2008. En su tesis, Amatullo definió el concepto de Design Attitude como (destrezas, capacidades, aptitudes) que los diseñadores aplican durante el proceso de diseño; las dimensiones de estas habilidades son: 1) tolerancia a la ambigüedad; 2) compromiso con la estética; 3 ) pensamiento sistémico [u holístico]; 4) capacidad de conectar múttiples perspectivas; 5) creatividad; y 6 empatía (Amatullo, 2015, pág. 97). diseñadores de actuar en el proceso tenga impacto y relevancia (Amatullo,
$2015)$, especialmente cuando se propone corresponde al trabajo de Richard manifiesta en muchos aspectos de la las distintas maras que tienen

las distintas maneras que tienen los
disenaadores de actuar en el proceso
creativo, ayudando a que un proyecto
tenga impacto y relevancia (Amatulto,
2015), especialmente cuando se propone
objetivos de innovación social.

of organizational knowledge (as quoted in of Michlewski's proposal lays in having outlined the following main categories of Design Attitude: 1) 'Consolidate

multidimensional meanings'; 2) 'creating, bringing to life'; 3) 'embrace discontinuity and open-endedness'; 4) 'embracing 'engaging a poly-sensorial aesthetics' quoted in Amatullo. 2015 p. 164 ). A third referent in Design Attitud 's conceptualization relates to the work of Richard Buchanan, who has defined it as the abilities and capacities of the designer, focusing his/her role towards the figure of a 'cultural explorer' 'as quoted in Amatulto, 2015). Likewise, Buchanan defines design as "a new liberal art of technological culture, manifested in many forms of professional practice perspective on the human-made world" (as quoted in Amatullo, 2015, p. 94). In this way, according to Amatullo, Buchanan's perspective offers a more multidimensional understanding of Desiga Thinking, closer to the philosophical thinking of authors like Richard Mckeon and John Dewey.

From this theoretical tour, Amatullo took the Design Attitude concept

to the realm of social innovation

dimensions, adapted from the categories proposed by Michlewski in 2008 . In her thesis, Amatullo defined the concept of Design Attitude as "a composite of distinct abilities (skills, capabilities, aptitudes) that designers apply during
the process of designing; the dimensions the process of designing; the dimensions of these abilities are: 1) ambiguity 3) systems thinking; 4 contecting multiple perspectives; 5) creativity; 6) empathy" (Amatullo, 2015, p. 97). All these dimensions systematize the different ways designers have of acting in the creative process, helping projects achieve impact and relevance (Amatullo, 2015), especially when dealing with

Design Attitude is a fundamental concern to invent new alternatives, to question and reveal presumptions that have become invisible and to offer new visions (as quoted in Amatullo, 2015).
DIMENSIONES DE DISEÑ DEACTITUD VALIDADAS EN EL ESTUDIO

DESIGN ATTITUDE DIMENSIONS VALIDATED IN THE STUDY

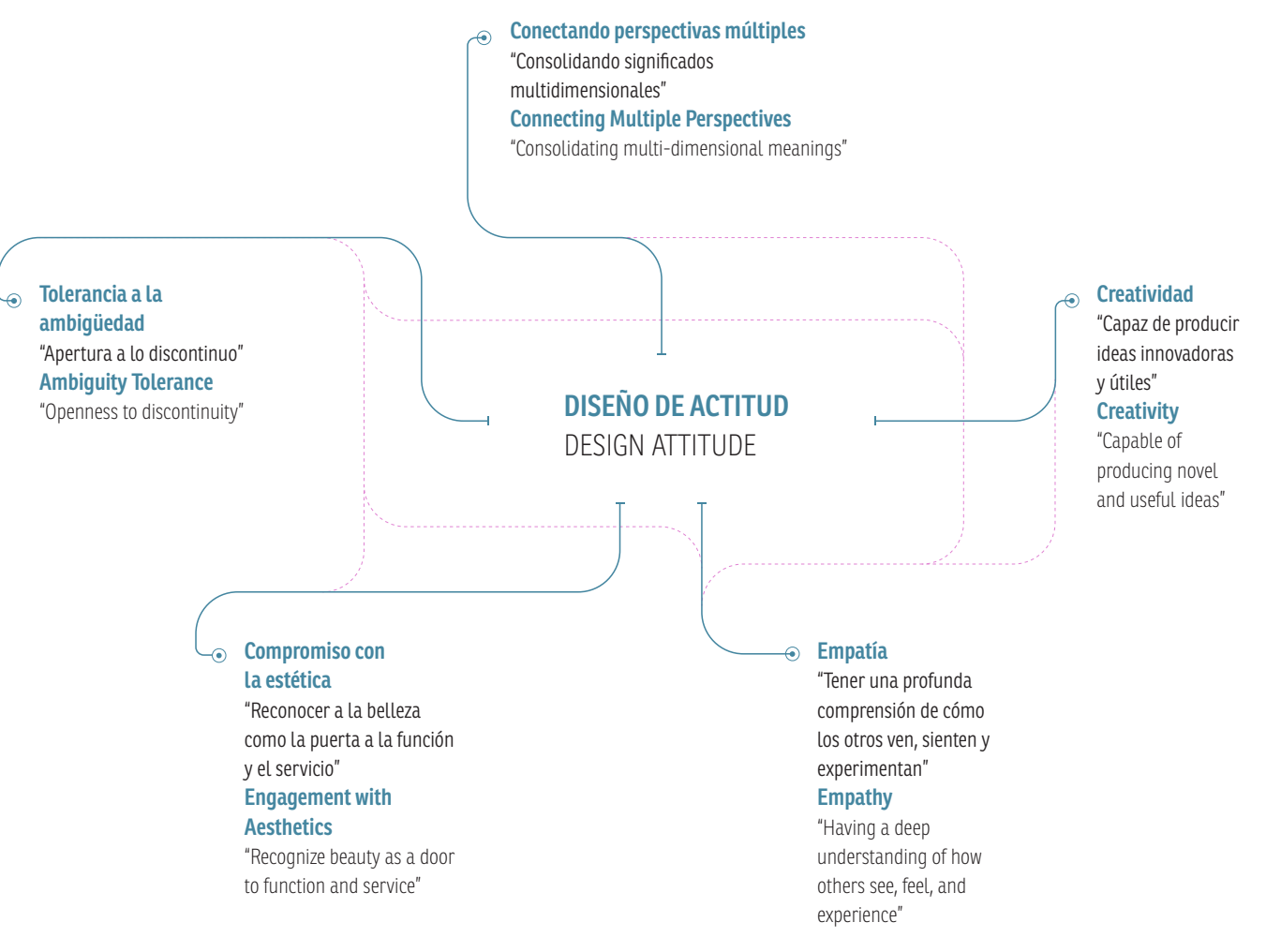

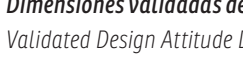

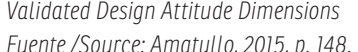

Design Attitude es una preocupación fundamental por

inventar nuevas alternativas, cuestionar y darse cuenta de presunciones que se han vuelto invisibles y ofrecer nuevas visiones (como se citó en Amatullo, 2015). 
DISEÑO DE INNOVACIÓN SOCIAL Tal como sintetiza Amatullo en su tes social se caracteriza por:

«El uso de métodos $y$ proximaciones centradas en la Jégou \& Manzini, 2008; Manzini 2014; Mulgan, 2014), en los cuales el proceso de diseño se extiende entre distintas competencias y partes interesadas (Bjogvinsson, Ehn, Hillgren, 2012) que son dirigidas hacia procesos de cambio social $y$ (Amatullo, 2015, pág. 102).

De acuerdo con este enfoque, prosigu Amatullo, los diseñadores pueden más allá de la cultura de consumo las lógicas de mercado (Brown, 2009) aportando sentido social a la práctica del diseño (Tromp, Hekkert, \& Verbeek, 2011)» (Amatullo, 2015, pág. 102).

Un rasgo distintivo es que en el contexto del diseño de innovación social,

«Muchos de los escenarios y muchas de Las formas híbridas que enfrentan los diseñadores en su práctica dan pie a situaciones
relacionales (Cipolla \& Manzini, relacionales (Cipolla \& Manzini, 2009) y deliberativas (Buchana de diseño se lleva a cabo

típicamente en medio de agendas intersectoriales (Mazé, 2014) y donde el papel del diseño a menudo se reposiciona fundamentalmente como una herramienta mediadora o estratégica de toma de decisiones y replanteamiento (Boyer et al.,
2011)» (Amatullo, 2015, pág. 102).
DESIGN FOR SOCIAL INNOVATION As synthesized by Amatullo in her Innovation is characterized by:

"experimentation and a pluralism of methods and approaches (Jégo \& Manzini, 2008; Manzini, 2014; Mulgan, 2014) in which the design process is spread among diverse participating stakeholders and competences (Bjogvinsson, Ehn, Hillgren, 2012) that are directed towards processes of social chang and transformation (Bund et al,

In accordance with this perspective Amatullo continues, designers can "go beyond consumer cutture and mark logics (Brown, 2009), and bring sociat significance to the practice of design (Tromp, Hekkert, \& Verbeek, 2011)" (Amatullo, 2015, p. 102). A distinctive feature is that, in the context of social innovation, "many of the scenarios and hybrid
forms of practice designers encounter open up relational (Cipolla \& Manz 2009) and deliberative situations (Buchanan, 1995) where design activity is typically conducted amids cross-sectorial agendas (Mazé, is often fundamentally repositioned as a mediating, or strategic decision making and reframing tool (Boyer et al., 2011)" (Amatullo, 2015, pág. 102)
Este marco conceptual enriquece y otorga espesor académico al llamado
que hace Amatullo a los diseñadores para que se comprometan con la acción, generando cambios $y$ alternativas al devenir social. La vicepresidenta de Designmatters es enfática al señalar que el diseno es una disciplina de para desarrollar posibilidades al futuro. Como señala Herbert Simon, el diseño tiene «el poder de imaginar $y$ crear un futuro mejor en este

momento de incertidumbre, de peligro y confusión» (como se cito en M. Amatullo,

\section{DESIGNMATTERS}

Amatullo promovió su visión del diseño a través de Designmatters, el departamento de innovación social del ArtCenter College of Design de Pasadena. Fundado en 2001, una especialización en innovación social en nueve disciplinas (ArtCenter s.f.). El departamento potencia el rol del diseñador como constructor de comunidad o catalizador cultural a partir de cuatro pilares temáticos: desarrollo sustentable, salud global, politicas pubblicas y emprendimiento
social. El departamento desafía los roles

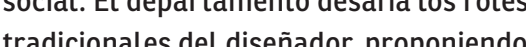
a los estudiantes desbordar los límites de su mera función de productores visuales (M. Amatullo, comunicación personal, 17 de enero, 2017).

Los proyectos de Designmatters constituyen experiencias educativas reales en contextos reales, lo que permite a los estudiantes desarrollar su capacidad de detectar problemas y poner a prueba las soluciones (Designmatters, de métodos colaborativos que involucra a las contrapartes $y$ un enfoque centrado en tres factores: el dinamismo,
This conceptual framework enriches Amatullo's call to all designers to eng in the action and generate changes of society. The vice-president of Designmatters is emphatic in pointing that design is a discipline of knowledge with an enormous potential for the future. As Herbert Simon points out design has "the power to imagine and create a better future in this moment of uncertainty, danger, and confusion" as quoted in M. Amatullo, persona communication, January 17, 2017).

DESIGNMATTERS

Amatullo has promoted her vision of design through Designmatters, The Department of Social Innovation at ArtCenter College of Design in Pasadena Founded in 2001, Designmatters currently offers a specialization in social innovation departiscipthes (Arcenter, n.d.). The designer as builder of communities or social catalyst based on four thematic pillars: sustainable development, global health, public policies, and socia innovation. The department challenges the traditional role of designers, encouraging its students to go beyond the timits of their function as mere visuall producers $M$. Amatullo, pers Designmatters' projects are real Designnatters' projects are real instructive experiences in real contexts, ability to detect problems and put to test solutions (Designmatters, n.d.). The projects are developed based on collaborative methods that involve the counterparts in an approach el emprendimiento y la experiencia, sin descuidar la excelencia. La colabora resultaría infructuoso aproximarse a diseño desde una perspectiva centrad

en la persona (Designmatters, s.f.). Este trabajo de diseño tiene un enfog pragmatista - para el que han sido importantes las ideas de John Dewey, Richard Buchanan y Richard Mckeonen poner a los alumnos en un contexto con un desafio, que ellos desarrollen conceptos e ideas y después trabaja con las organizaciones con las que nos involucramos (...) para co-crear soluciones» (M. Amatullo, comunica personal, 17 de enero, 2017). Así, las los estudiantes, sine que surgen a par de la eriencin indagan qué pueden aprender al

someterse a una inmersión completa considerar disciptinas ajenas al dise para alimentar las ideas de diseño 17 de enero, 2017).

A continuación, exponemos dos proyectos recientes de Designmatters que vinculan el diseño y la politica hasta aquí. En el primero de ellos, Safe Niños, realizado en Chile en 2016, resalta la importancia de los métodos y las técnicas responsivas a contexto y orientadas a la colaboracion, especialmente cuando el diseñador busca comprender las experiencias para desarrollar soluciones en conjer a proyecto, Fresh Eyes Cuba, desarrollad entre 2016 y 2017, se transforma en una intensa experiencia de aprendiza y colaboración intercultural entre estudiantes estadounidenses y cub Este proyecto es una experiencia privitegiada para ta formación ciudadanos de un mundo en prime la tolerancia. nnovation, and experience, without compromising excetlence, when it comes to collaboration, it requires empathy, approach design from a human-centered This design work has a pragmatic Dewey Richorich, the ideas of John Dewey, Richard Buchanan and Richard Mckeon have been relevant-: "The students in context facing a che so they can develop concepts and ideas and work with the organizations with which we are involved (...) to co-create solutions" (M. Amatullo, personal

communication, January 17,2017$)$. In this way, the solutions are not preconceived by the students, but emerge from the experience in the organization where the they can learn by subjecting the mentres to a full immersion and by considering disciplines foreign to design to nurture the design ideas (M. Amatullo, personal communication, January 17, 2017). Next, we will present two recent
projects by Designmatters that link together design and politics in the sense that has been proposed here. The first one, Safe Niños, done in Chile in 2016, hightights the importance of methods and techniques responsive to the context especially when the designer seeks to understand the experiences in order to develop solutions together with the organization and the different social agents involved. The second project, Fresh Eyes Cuba, developed between 2016 and 2017, is an immersiv cultural collabornation ana crossand Cuban students. This project is an exceptional experience in the education of designers that can also be citizens of a world where tolerance is the norm. 
SAFE NIÑOS

NTECEDENTES

Cada año, más de siete millones de niños sufren quemaduras en ArtCenter College of Design, 2016) Muchas veces estos accidentes demand varios años de tratamientos destinados a superar las consecuencias físicas y psicológicas que ocasionan. Se trata de procedimientos caros que requiere la participación de fisiatras, médicos, cirujanos, dermatologos, pediatras, cenpacion, sis psićl trabajadores sociales, terapeutas musicales y pedagogos, entre otros profesionales (Saavedra, 2016). Debido a su elevado costo, muy pocas familias están en condiciones de costearlos.

Desde su creación en 1979, la fundación chilena COANIQUEM ha brindado atenciôn holística y gratuita a más de ciento veinte mil niños de escasos recursos que con impos signifeavos en susvidas (Roj-Zers 2016; Design at ArtCenter College of Design, 2016). Durante sus primeros años la corporación llevaba a cabo su labor en la Unidad de Quemados del Hospital Roberto del Río (COANIQUEM, s.f.). Actualmente, con el apoyo de una extensa red de donantes y un presupuesto anual que supera los
cuatro millones de dólares, COANIOUEM de los cuales viajan desde diversos puntos de Sudamérica y El Caribe-

un campus de 25 mil metros cuadrados ubicado en Santiago, así como en sus sedes regionales de Antofagasta y Puerto Mont (Designmatters at ArtCenter College of Design, 2016; COANIQUEM, s.f.). Junto con las sesiones de curación y rehabilitación las prestaciones incluyen el alojamiento de los fan es campus de ta instisy de salud, COANIOUEM pone en práctica los principios del diseño participativo, tal como señala su director médico: «nuestro equipo, la comunidad, el paciente y su familia trabajan juntos diseñando e implementando un plan de tratamiento que considera las necesid del paciente en base a su situación
individual» (Saavedra, 2016, pág. 18).

\section{SAFE NIÑOS}

Every year, over seven millio

Designmatters at Artcenter College of

Design, 2016). These accidents frequently

require many years of treatment to

help them overcome their physical and

psychological consequences. These

are expensive procedures that require

participation of physiatrists, physicians, surgeons, dermatologists, pediatriciala, therapists, psychologists, nutritionists, social workers, musical therapists and educators, among other professionals (Saavedra, 2016). Due to their high costs, very few families are able to afford them. Since its creation in 1979, the Chilean foundation COANIQUEM (Spanish acr for Corporation for the Aid of Burnt Children) has provided holistic and free children that har 120,000 underprivileged burns with sinvififirtered devastating (Rojas-Zegers 2016: Designmatters at ArtCenter College of Design, 2016). Durin its first years, the foundation carried ou its work at Roberto del Rio Hospital's Burnt Unit (COANIQUEM, n.d.). Presently, with the support of a vast network of donors and an annual budget which exceeds four million Dollars, COANIQUEM provides services to elght thousand from different toar - some of them trave and the Caribbean - in its 25,000 square meter campus located in Santiago, as we as in its regional facilities in Antofagasta and Puerto Montt (Designmatters at ArtCenter College of Design, 2016; COANIOUEM, n.d.). Besides the treatment
and rehabilitation sessions, the services and rehabilitation sessions, the services Include living accommodations for the
families for weeks and even months in the families for weeks and

Even though it is a health organization, principtes of partinto practice the Medical Director points out: "Our staff, the community, the patients and the patients' families work together in designing and implementing a treatment plan that considers the needs of the patient based on his or her individual situation (Saavedra, 2016, p. 18). This inclusive
Esta aproximación inclusiva y forma de responder a sas necesida un específicas que presenta cada caso, representa una oportunidad para establecer colaboraciones fértiles en las que el diseño puede hacer un gran aporte tal como quedo demostrado con las 2016 por los alumos del Artcenter.

Cabe hacer notar que no se trataba de caberimas cooperaban. En la primavera de 2013 el Departamento de Diseño Gráfico de ArtCenter albergó un proyecto denomin The Healing Cloud. Dicha iniciativa,

cuyo propósito fue desarrollar mensajes positivos de prevención de quemaduras incrementar el apoyo a niños que las han sundo en cuaro passes lathoamericanos, de Design stors copartícipe (Designmatters at ArtCenter College of Design, 2016). Tampoco era la primera vez que Designmatters operaba en Chile, ya que entre 2009 y 2014 había desarrollado el proyecto Safe Agua junto a la ONG Techo (Amatullo, 2016). En el caso de Safe Niños, un proyecto de Desingmatters concebido por el Departamento de Diseño Ambiental, liderado por Penny Herscovitch, Daniel estudiantes Sula Hezar, los un nuevo ambiente para línica A su vez, ellos debían introducir mejora en las diversas etapas del proceso de recuperación de los niños quemados, trabajando en conjunto con una institución que promueve el autocuidado y el su propio tratamiento (Saavedra, 2016).

«El proceso de rehabilitación puede tomar un promedio de 12 años, y los niños deben pasar por una serie de IOtratamientos distintos, cada uno punto de vista un niñ meso cinco años - el paciente típico de COANIQUEM - se trata de recintos $a$ los que tienen que ir $y$ cosas que tienen que hacer. La meta de COANIQUEM es llenar esos espacios de alegría, asombro y esperanza» (Designmatters at ArtCenter Colleg and trans-disciplinarian approach that specific needs that each case implies, represents an opportunity to establish fruitful collaborations where design can make a great contribution, as was demonstrated by the interventions $c$ out in 2016 by ArtCenter students. It's worth pointing out that this wasn collaborated. In the spring of 2013 ArtCenter's Graphic Design Departm hosted a project called The Healing Cloud. This initiative, whose purpose was to develop positive messages regarding prevention of burns, and to increase the support for children that had suffered them in four Latin American countries, was the first transdisciplinary study of Designmatters with COANIOUEM as collaborator (Designmaters at ArtCenter first time that Designmatters operated in Chile, since between 2009 and 2014 it had developed the Safe Agua project toget with NGO Techo (Amatullo, 2016). In the case of Safe Niños, a Designmatters project conceived by the Environmental Design Department and led by Penny Herscovitch, Daniel Gottlieb and Stella Hernández, students were challenged to conceive a new

introduce improvements in div had to in the recovery process of burnt children, working side by side with an institution that promotes self-care and patients' engagement with their own treatment (Saavedra, 2016).

"The rehabilitation process can span an average of 12 years, and children must go through a series of 10 different treatment types, each covering specific functions. To a child under 5, - COANIQUEM's typical patient-, they 're Just rooms they do. COANIOUEM's goal is to fill those rooms with joy, wonder and hope" (Designmatters at ArtCenter College of Design, 2016, p. 16
Muchas de las principales dificultades COANIOUEM Lstán relacionales de asuntos de diseño. Los niños sienten rechazo hacia la estetetica de los accesorios de compresión que deben usar para proteger sus cicarrices, as que les recuerdan constantemente que les recuerdan constantoment oponen resistencia cuando deben ser tocados en las zonas afectad 2016). Todo ello hace difícil que los niños dejen atrás el trauma de las quemaduras $y$ recuperen una imagen positiva de sus cuerpos (Campos, 2016). En este sentido 作 todas estas actividades puede ser iofrece una experiecia atrativa ú́dica que ayude a los niños a dejar atrás el miedo (Campos, 2016).

Porque lo cierto es que las

características ambientales son vitales en el proceso de curación. Como señala la doctora Esther Sternberg, autora del libro Espacios que sanan: la ciencia del espacio y el bienestar y asesora de los estudiantes del ArtCenter, el espacio y thar pueden camblar la marcha de «Podemos entender cómo la percen ensorial gatilla emociones que hacen fluir moléculas en el torrente sanguíneo y las células nerviosas. Y ahora sabemos cómo esas moléculas pueden afectar el sistema inmunologico y su habilidad para
curarnos» (Sternberg, 2016, pá́. 22). Por eso la misión original los 15 alumnos seleccionados por Designmatters para desarrollar el proyecto en Chile era diseñar espacios de Santiago (Rojas-Zegers, 2016) «Las instalaciones ya no serían las de un centro de salud blanco y plano. Los nuevos $y$ atractivos ambientes responderían a las necesidades de los niños y sus familiares, pero también serían acogedores, divertidos $\mathrm{e}$ interactivos» (Rojas-Zegers, 2016, păg. 7). Más aún, los espacios contribuiría al propostio de COANDUEM: que tos en la institución mejoran a form que enfrentan su proceso de curación (Rojas-Zegers, 2016).

Many of the crucial difficulties that professionals at COANIOUEM have to face are related to design issues. Children the compression devices they must use to protect their scars, as well as to th orthopedic elements that constantly remind them of the trauma of their burns. affected areas (Campos, 2016). All of this makes it hard for the children to Leave behind the trauma of the burns and regain positive image of their bodies (Campos, 2016). In this sense, the environment where alt these activities take place can provide an a relevant, especially if it can that an altactive, playtul experience hat can help children overcome their Because the truth is that environmenta process. As expressed by Dr. Esther Sternberg, author of the book Healing Spaces: The Science of Place and WellBeing and advisor for the ArtCenter students, the space and the place can change the course of a disease and underste the healing process. "We can terstand how sense perceptions trigger through our blodstrean as nowng those molecules can fect the immune system and its ability to .

Safe Niños. Niños Seguras For this reason, the original mission of 15 students selected by Designmatters to devign innove troject in Chile was to for the Santiago facilities (Rojace 2016). "The facility would no Longer be plain, white, institutional health center. The new, engaging environments would fients and parents, 
En este sentido, el ambiente en el que se desarrollan todas estas actividades puede ser

tremendamente importante, sobre todo si ofrece

una experiencia atractiva y lúdica que ayude a los

niños a dejar atrás el miedo (Campos, 2016).
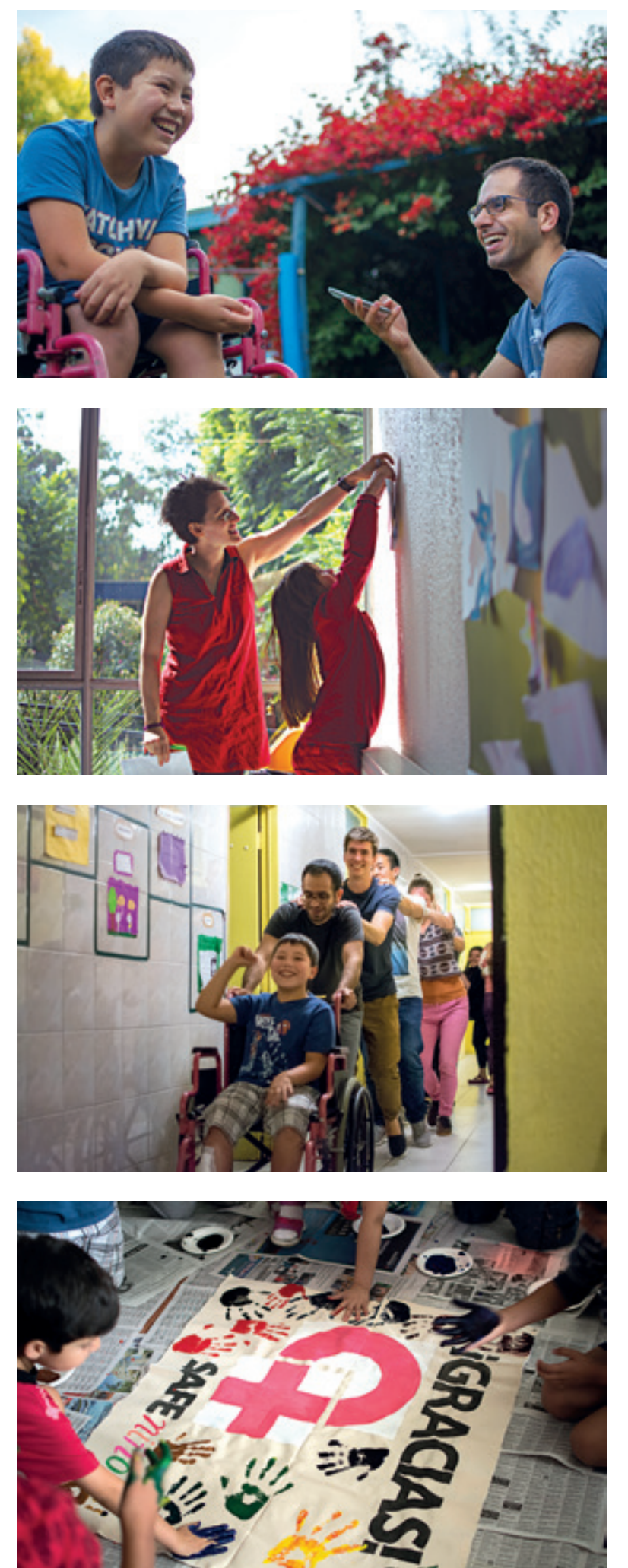

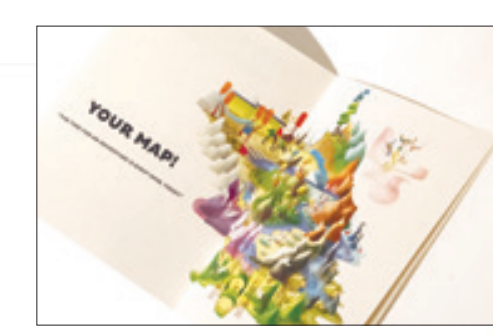

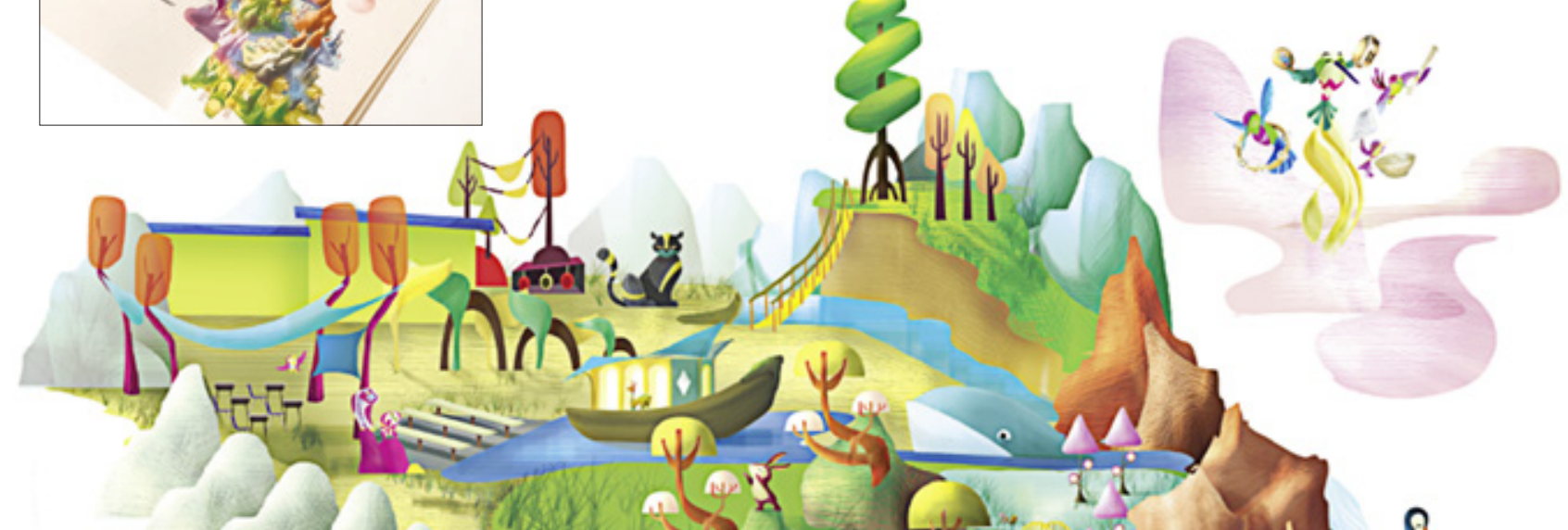

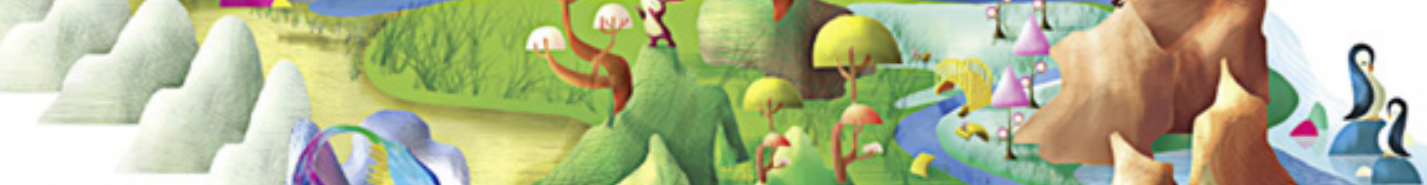

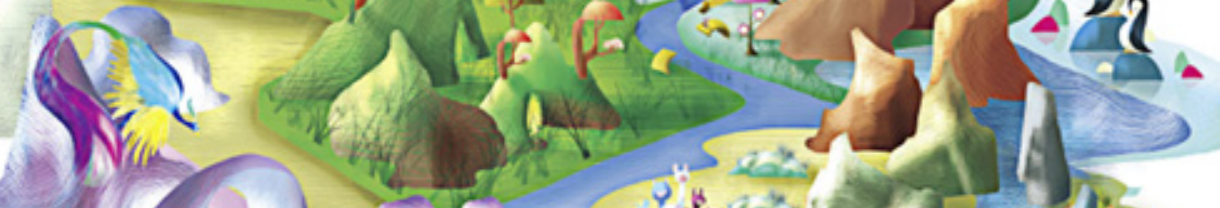
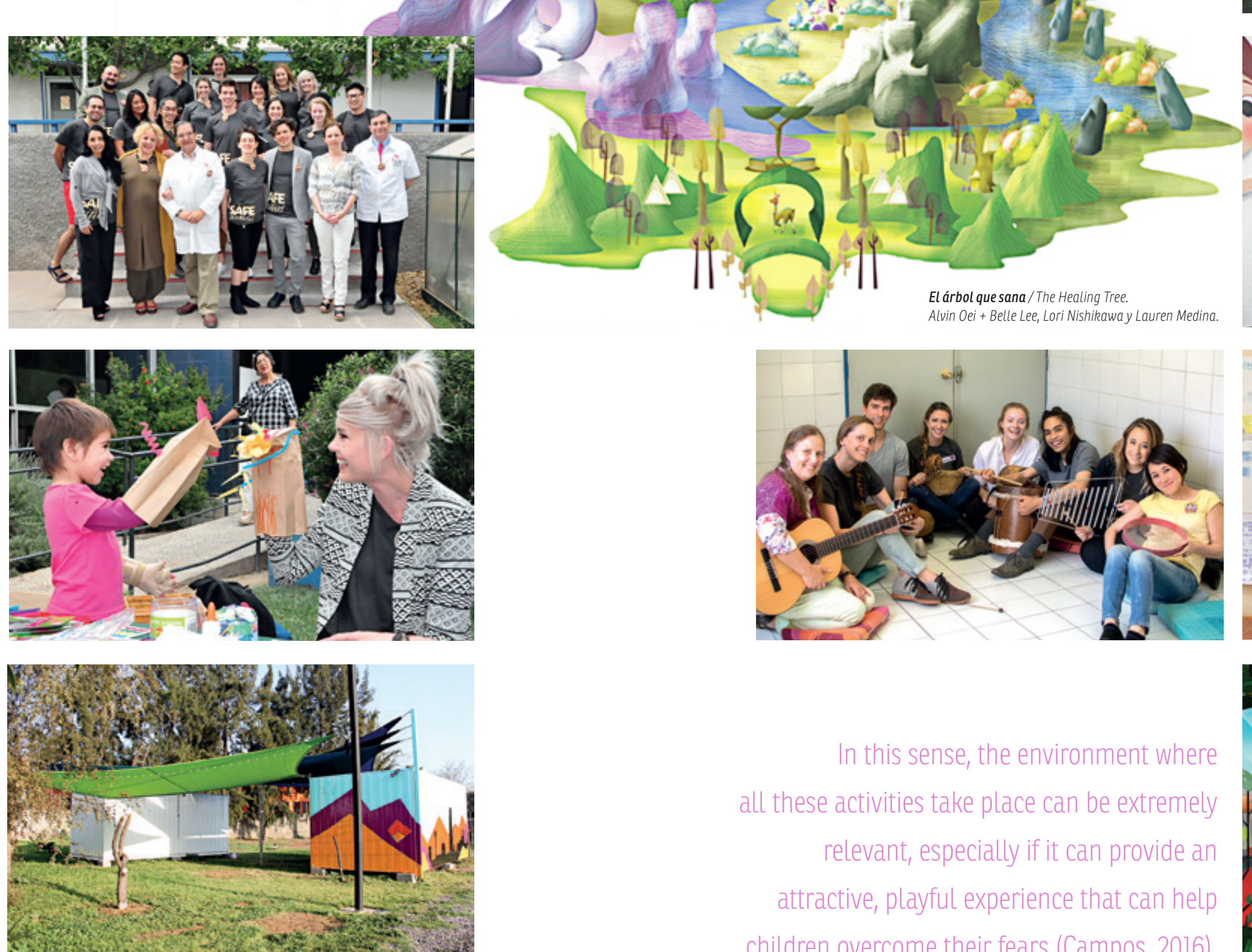
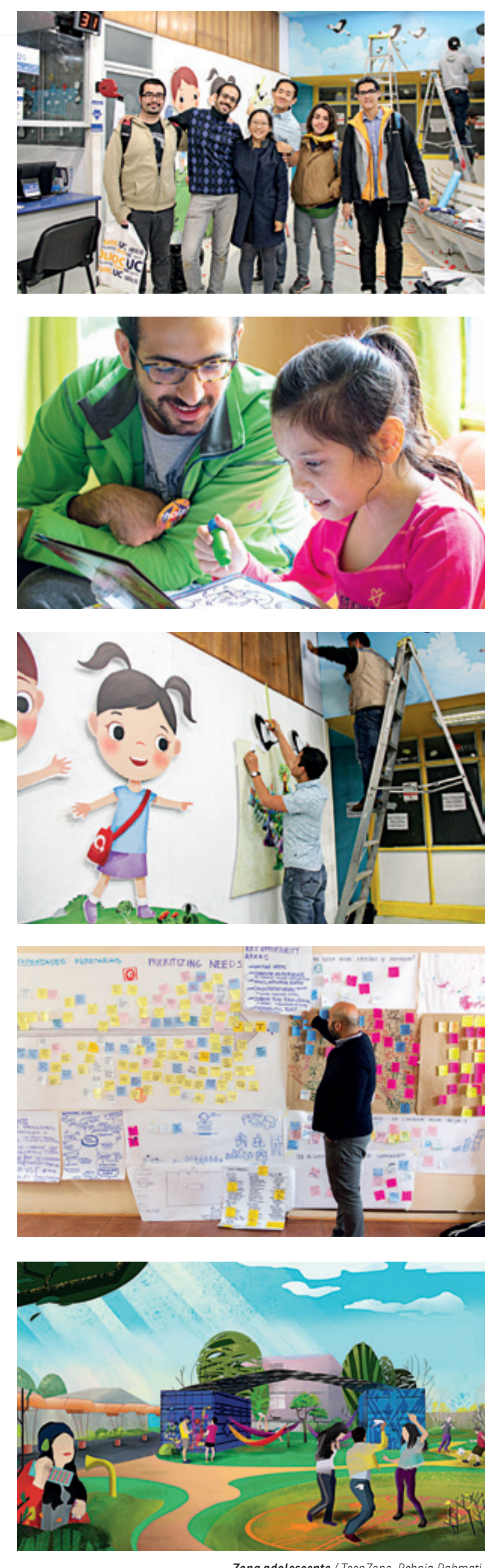
METODOLOGÍA

El proyecto fue realizado en varias fases. un proceso de preparación previa de trabajo conjunto con COANIOUEM, el desarrollo de ta solución en Pasaden una segunda etapa en Chile para testear los prototipos $y_{\text {, finalmente, }}$ ta evaluaciôn del impacto y el análisis de la oportunidad de repleabildad

Visto en detalle, el trabajo de los ll etapas (ver Infografi) Antes de

viajar a Chile para realizar la primera

investigación de campo, los estudiantes recibieron formación metodológica en etnografía para levantar información generar datos y trabajar con

estadisticas; a su vez, la cocreacion

fue adoptada como técnica de

investigacion de diseño (Designmatters

Los estudiontes te oriesign, 20

informados sobre los diversos as

de carácter médico-psicológico que

serían fundamentales para el trabajo

con la fundación, conocimientos que

además fortalecerían la confianza de la

institución en el rol que el diseño po

ejercer en el proceso de sanación de

los nirosy en el apoyo a sus fantilias;

ad

enfrentaban delicados tratamientos de

sanación asi como con sus familiares

(Designmatters, 2016a). Cabe destacar

el workshop de sensibilidad orientado

a que los estudiantes desarrollaran

una relación empática con los niños

de COANIQUEM y sus familiares,

quienes muchas veces experimentan

senter

y depresion (Designmatters

Ya en terreno, los estudiantes

saron herramientas y técnics con

entrevistas cualitativas, observación

participante, sondas culturales, un di

en la vida de los pacientes, sesiones

de investigación a través del arte y e

juego y brainstorming, varias de las

cuales habian sido codificadas por

académicos del Artcenter a través de

cartas metodologicas y un manual-

auta de investigación (Designmatters project was carried out in

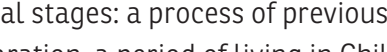

and working together with COANIQUEM

the development of the solutions in

Pasadena, a second stage in Chile to

test the prototypes, and finally, the

evaluation of the impact and the analysis

of the opportunity for replicability
(Designmatters, 2016a).

Seen in detail, the work of the ArtCenter (a)

students received methodological training

in ethnography to collect information,

generate data and work with statistics; at

the same time, co-creation was adopted

as a technique for research in design

(Designmatters at ArtCenter College of

Destyn, 2010. He students were also

aspects that mont

with the foundation, a body of knowledge

hat would also strengthen the confidence

of the institution on the role that design

could play in the healing process of the

(itdren and the support of their families;

additinally, they received training on how

作

well as with their relatives (Designmatters

.

workshop on sensitivity aimed at making

he students develop an empathic relation

toward the children at COANIQUEM and

eetings of anguish, fear, guilt and

College of Design, 2016).

Once in the field, the students used

fools and techniques such as qualitative interviews, participant observation,

patients, research sessions through art and

play, and brainstorming, many of which

through methodology charts and a

research quide-handbook (Designmatters

at ArtCenter College of Design, 2016).

«Sobre todo, se animó a los

estudiantes a ser empáticos

buscadores de oportunidades

en lugar de solucionadores

instantáneos de problemas»

(Designmatters at ArtCenter

opportunity seokers rather than instant probtem sotvers'

(Designmatters at ArtCenter College of Design, 2016, p. 31).

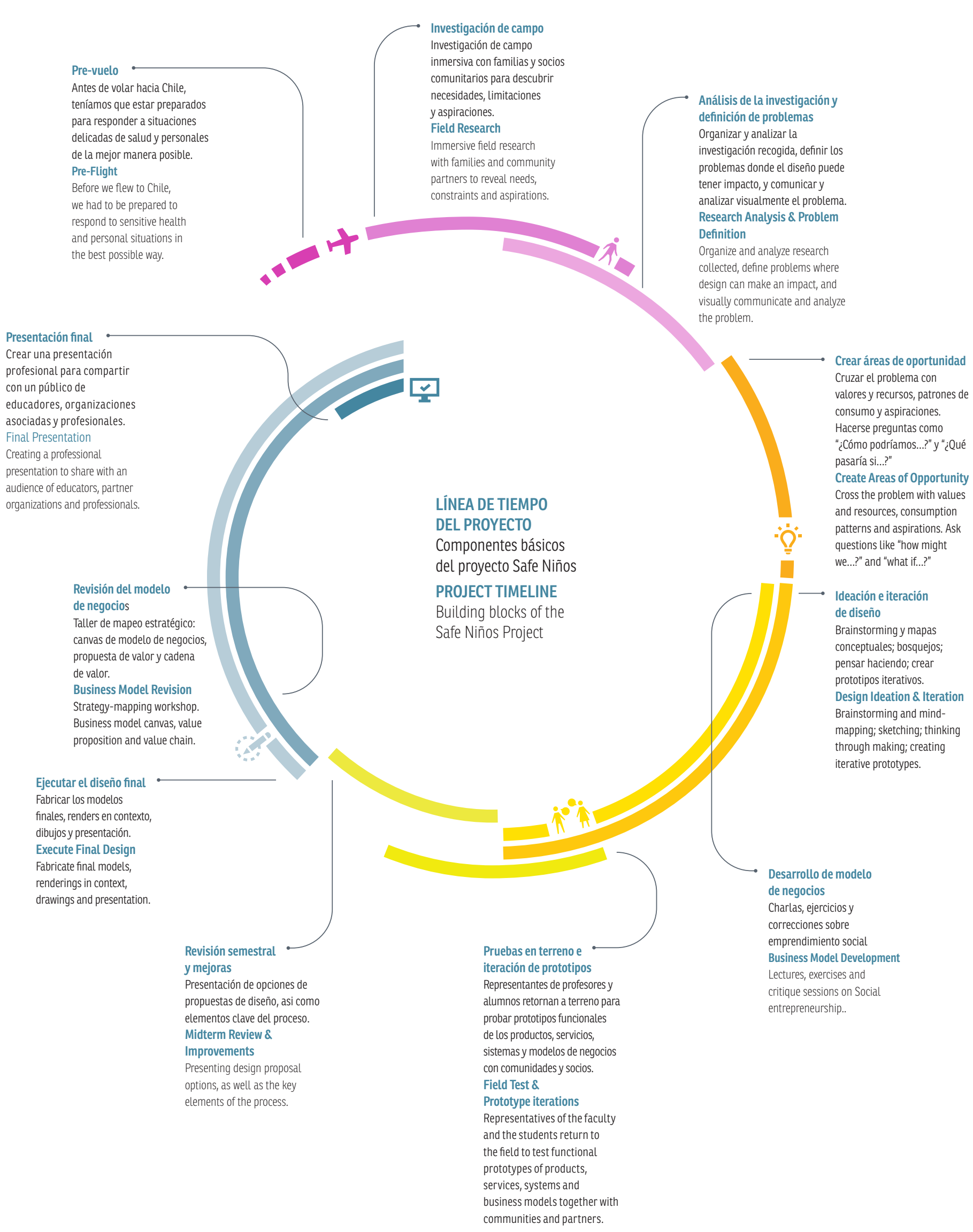

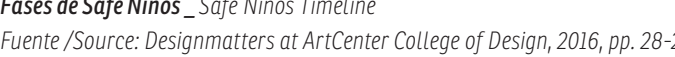


Así, mediante diversos workshops semanas, los alumnos pudieron obse el comportamiento de los grupos de interés y detectar los momentos clave y las actividades importantes, especialmente la experiencia de Los niños desde el momento en que proceso de identifcaión que tanto el como el desarrollo de las soluciones se realizarían de manera colaborativa con los miembros de la institución, se procuró encontrar interlocutores que pudieran participar en este proceso cocreación de ta propuesta de diseño (Designmatters, 2016a). «Sobre todo, se animo a los estudian de solucionadores instantáneos de problemas» (Designmatters at ArtCenter College of Design, 2016, pág. 31).

Para alcanzar consensos, comunicar escenarios, priorizar las decisiones de foco en los usuarios, los estudiantes usaron la herramienta "personas", desarrollada por el disenador de interacción Alan Cooper a fines de los noventa (Designmatters at ArtCenter

Durante los útimos días de su

prera estada enchice, los alumnos analizaron cómo interactuaban con ellos los pacientes. Inspirados por el modelo holístico de COANIQUEM, habían resuelto dejar atrás el esquem de grupos de trabajo propuesto por ArtCenter y actuar colaborativamente como un solo equipo. (Designmatters ArtCenter College of Design, 2016.

LA PROPUESTA

De vuelta en Pasadena, los estudiantes de ArtCenter trabajaron en distintos

ámbitos del diseño (diseño ambiental, ilustración, diseño de productos, diseño interacción y diseño industrial), guiado

de la facultad. El objotivo fue cents

ambientes acogedores, terapéuticos

alegres e interactivos que recogieran

las necesidades de los pacientes, sus
Thus, through different successive workshops over a two-week period, were able to observe the dehaviour of the interest groups and cey moments and important

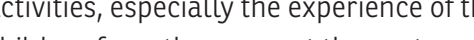
the faities. Snce Dont they entered problem identification, as well as the development of solutions were to be in collaboration with the members of the institution, efforts were made to find interlocutors that could participate in this process of co-creation of the design proposal (Designmatters, 2016a). "Ab all, students were encouraged to be mpathic opportunity seekers rather th at ArtCenter College of Design, 2016, $p$.

To reach consensus, communicate The the students used the "personas" tool, developed by interaction designer Ala Cooper in the late 90's (Designmatters ArtCenter College of Design, 2016). stay in Chile, the ArtCenter students built the prototypes and analyzed how patients interacted with them. Inspired in COANIOUEM's historic holistic model, hroy decided to leave behind the work and scolne pros a sing (Designmatters at ArtCenter College of Design, 2016).

\section{THE PROPOSAL}

Back in Pasadena, the ArtCenter

of design (interior design, illustration, product design, interaction design and ndustrial design), guided by the expert

environmental faculty team of Safe Niños. The aim was to create lively, interactive and therapeutic environments that could needs of the patients, familiares y los equipos de salud

(Designmatters at ArtCenter College of Design, 2016). Las soluciones inclúian
intervenciones en las salas de espera, en las áreas de juego y aprendizaje y en diversos sistemas en el campus, asi como la creación de superficies interactives En total se desarrollaron seis proyectos: El muats Welcoming Entry: The Therapeutic Play Patio; Sensory \& Therapeutic PlatScape; y El Club TeenZone. Las propuestas de diseño fueron sometidas a pruebas, correcciones y testeos. En una segunda visita a Santiago, dos alumnos testearon las ideaciones y los modelos Lasonios Las soluciones implementadas en COANDUEM fueron creadas a personajes imaginarios aue contribur a que los niños asumieran mior las etapas de curación. En concreto, se proyectaron animales-personajes que experimentaban situaciones similares a Las de los pacientes. Estos personajes, cuya caracterización correspondía a especies asociadas al territorio chileno, fueron aplicados a través de del recinto, en reemplazo del antiguo lenguaje clínico y aséptico del lugar.

\section{«El pudú (...) vive en el taller de} confecion de accesorios, usa necesarios para el tratamiento y enseñará a los niños a sentirse orgullosos de ser diferentes. El puma, cuyo hábitat es el área de la cirugía, les enseñará a ser valientes, y la ballena mostrará a los pacientes que no hay nada que Zegers, 2016, pág. 7).

Estos personajes, representados con una estética amistosa y adecuada para nién en plros, freron incluidos tienen acceso los pacientes, generando un ecosistema mágico que incorporaba el color como elemento protagónico. their families and the medical stafff. (Designmatters at ArtCenter College of nterventions in the play and learn areas and in different systems in the campus, like the creation of interactive surfaces, furniture, lighting and signage. In total six projects were developed. Santis

The Therapeutic Play Patio: Sensory \& Therapeutic PlatScape; and the Tenz The design proposals were subjected to testing, corrections and checks. In a second visit to Santiago, two students tested the ideas and conceptual models produced in California

The solutions implemented in COANIQUEM were created based on the narratives proposed by imaginary characters that helped the children face process Specifically. anim of their healing were conceived that had to undergo similar situations as the patients. Thes characters, whose portrayal correspon to species associated to the Chilean territory, were used in illustrations is different spaces within the premises, replacing the old hospital-like and asep anguage of the place.

"The pudú (...) lives in the fitting workshop, wears the compression

garments needed for therapy and wicteach difernt the bu proud habitat is the surgery area, will teach them to be brave, and the whale will show patients that there is nothing to fear from hydrotherapy" (RojasZegers, 2016, p. 7 .

These characters, represented with friendly aesthetics, appropriate for sma children, were included also in other media that the patients had access to, generating a magical ecosystem that
La propuesta también desarrolló conceived for adolescent patients,
didolescentes, quienes muchas veces, por
who frequently, for diverse reasors diversos motivos, interrumpen su proceso interrupted their treatments. Following de curación. Siguiendo la perspectiva colaborativa del proyecto $y$ a partir Hna necesidad detectada durante el para los jovenes se imptra un espacio solución de diseño ambiental titulada El Club: TeenZone, que dio vida a containers existentes - que no estaban siendo usados-a partir de contribuciones artísticas y arquitectónicas

especial dedicada a las terminaciones

que se debieron hacer en ArtCenter

y una permanente interacción con

las personas que participaron de esa

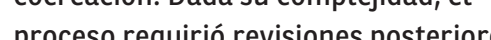

su puesta en marcha para asegurar que la visión original fuese implementada de acuerdo con el plan previsto. Estas revisiones permitirán replicar et modelo en instituciones similares en otros países. Al concluir el estudio se hizo una presentación final a una audiencia de educadores, miembros de organizacios a a a proyecto (Designmatters, 2016).

Tanto el planteamiento del problema como la solución aparecen, en este caso, experienciaenterreno-en diversas metodologías cuidadosamente aplicadas-. En este contexto, es

interesante resaltar las palabras con que el presidente ejecutivo de COANIQUEM agradeció esta intervenciós:

"Gracias por ayudarnos a mejorar, a traves del diseño, nuestra calidad de atención. Nuestro objetivo es especialesy amados en COANIOUEM. El nuevo entorno complementará este enfogue y mejorará la forma en que los niñosy los padres se (Rojas-Zegers, 2016, pág. 7). ve approach of the

project and based on a necessity that was detected in the field study - there wasn'ta space for young people - , an TeenZone was implemented, bringing new life to existing containers - that wer not being used - based on artistic and architectural contributions by the young patients (Rahmati, 2016). dedicated to complete the finishes

that had to be done at ArtCenter, and who participated in this co-creation. (n) is complexily, he process

original vision was materialized according to plan. These revisions will allow to replicate the model in similar institutions other countries. At the conclusion of the study, a final presentation was made to an audence of educators, members of (t) (Designmatters, 2016a).

Both the formulation of the problem, as well as the solution, emerged, in this case feld experience - enriched with different, carefully applied methodologies. In this context, it is interesting to highlight the words with which COANIQUEM's executive president thanked this intervention:

Thank you for helping us to improve, through design, our quality of care. and toved at COANIQUEM. The new children and parents face the healing . 
contribuyendo al potente resultado de la students and contributed to the strong de enero, 2017)

Otro factor que incide en los resultados es la visión de Amatullo con Designmatters. Ella no se ciñe a una

divion entre las disciplinas del diseño la búsqueda de la funcionalidad o la contemplach katratesecta

«Intento, quizá por mi formación - porque soy historiadora del arte museóloga - no ver esas diferen [arte-diseño]. Las respeto y las entiendo pero (...) hay una dimensión muy artística en la funcionalidad $y$ no me gusta diferenciar tanto las disciplinas. (...) Creo mucho en la dimensión estética del diseño (M. Amatullo, comunicación
personal, 17 de enero, 2017).

Fresh Eyes Cuba constituye una experiencia privilegiada de educación de a y que promeve desarrollo de ta conciencia socialy polisca de los mirada abierta ante las situaciones de conflicto aparece a partir de una experiencia práctica de diseño, demostrando que es posible hacer diseño muy formaty riguroso involucrándose con

contexto politico y social colindante.

«La dimensión social de este proyecto tiene también una dimensión mucho mas personal mividual. Cada cual (...) vivio para siempre como persona y como diseñador. Después de esta experiencia como creadores, [los estudiantes] tienen otra conciencia social (...). Es otra manera de llegar a la conciencia social, que no es por medio del outcome, sino una conciencia social que generas en elindivido, en el creador. Yeso más importante. (...) La esperanza es que ellos puedan tomar eso y desarrollarlo en sus carreras de otra forma, a largo plazo» (M. Amatullo, comunicación
personal, 17 de enero 2017). a different way, in the communication, Jar
REFLEXIONES FINALES

Los dos proyectos expuestos se
constituyen en referentes del diseto comprometido con la transformación positiva de la sociedad. En ambos casos, las herramientas de coparticipación resultan vitales. Safe Niños reafirma la este caso COANIOUEM y la especio atención brindada por Designmatters a las problemáticas locales. También representa un modelo de trabajo centrado en la colaboración. En este caso, el diseño no solo se vuelve una herramienta para contribur a la calidad de ta atención n sald, sna calde la diversidad de contextos en que el diseño puede aportar a generar cambios sociales, comunitarios y territoriales, sin que la disciplina pierda su naturaleza. Amatullo destaca que Safe Niños se consolidó como una instancia de diálogo con otras disciplina yorras expín parsonat 17 a de vida, 2017).

\section{Fresh Eyes Cuba es una de esas}

disciplina, dejan frutos que van $m$

allá de la solución obtenida, que

pueden llegar a tener impactos futuros

impensables, transformando a los

estudiantes en agentes de cambio social,

en ciudadanos globales tolerantes,

diversas realidas mirándolo todo a nuevos ojos: con ojos frescos.

Finalmente, cabe preguntarse, cómo Mariana Amatullo tiene éxito a través de la plataforma educacional Designmatters dada la escala de complejidad asociada a un proyecto de diseño en innovación social. Esto constituye una problemática relevante a la hora de considerar el aporte del diseño en el ámbito de la soluciones creadas para estos proyectos responden a una realidad social y cultura específica, el desafío también está en su sustentabilidad y la replicabilidad. Para Amatullo, la replicabilidad de un solución en innovación social solo es proyecto se ha comprobado en la práctica y su estructura ha sido bien estudiad, revisada y perfeccionada (comunicación personal, 17 de enero, 2017). Su aproximación tan mesurada y deliberada hace que todo esto pueda ocurrir. pertinencia de la propuesta en relación

FINAL THOUGHTS

The two projects presented stand out as examples of a design committed to a positive transformation of society. In are vital. Safe Niños reaffirms the pertinence of the proposal in relation to the work of an organization, in this case, COANIOUEM, and the special attention issues. It also represents a whe local centred on collaboration. In this case, design not only becomes a tool to contribute to the quality of health care but becomes a remarkable example when it comes to imagining the diversity of contexts where design can contribute in generating social, communitarian and territorial change, without it losing its nature. Amatulto underlines that Safe of dialogue with other disciplines and other life experiences and stories (M. Amatullo, personal communication, January 17, 2017).

Fresh Eyes Cuba is one of those experiences that, constructing discipline, leave behind results that go beyond the solution obtained, that may have unforeseen future impact, transforming the students into agents of social change, tolerant global citizens different realities, seeing it all with new eyes: fresh eyes.

Finally, it is worth asking how does Mariana Amatullo succed through the Mariana Amatulto succeed through the
educational platform of Designmatters given the scale of complexity that social innovation projects entail? This is a relevant question when assessing the unique contributions and potential of design in the field of social innovation. Considering that solutions for such projects (end to be connext-spectic and must

the challenge at hand also becomes one of sustainability and replicability For Amatullo, the replicability dimension of a design solution can only become a reality after a project's viability and feasibility are carefully accounted for (personal communication, January 17, 2017). Hers is a measured and very del berate approach to making it all happen.
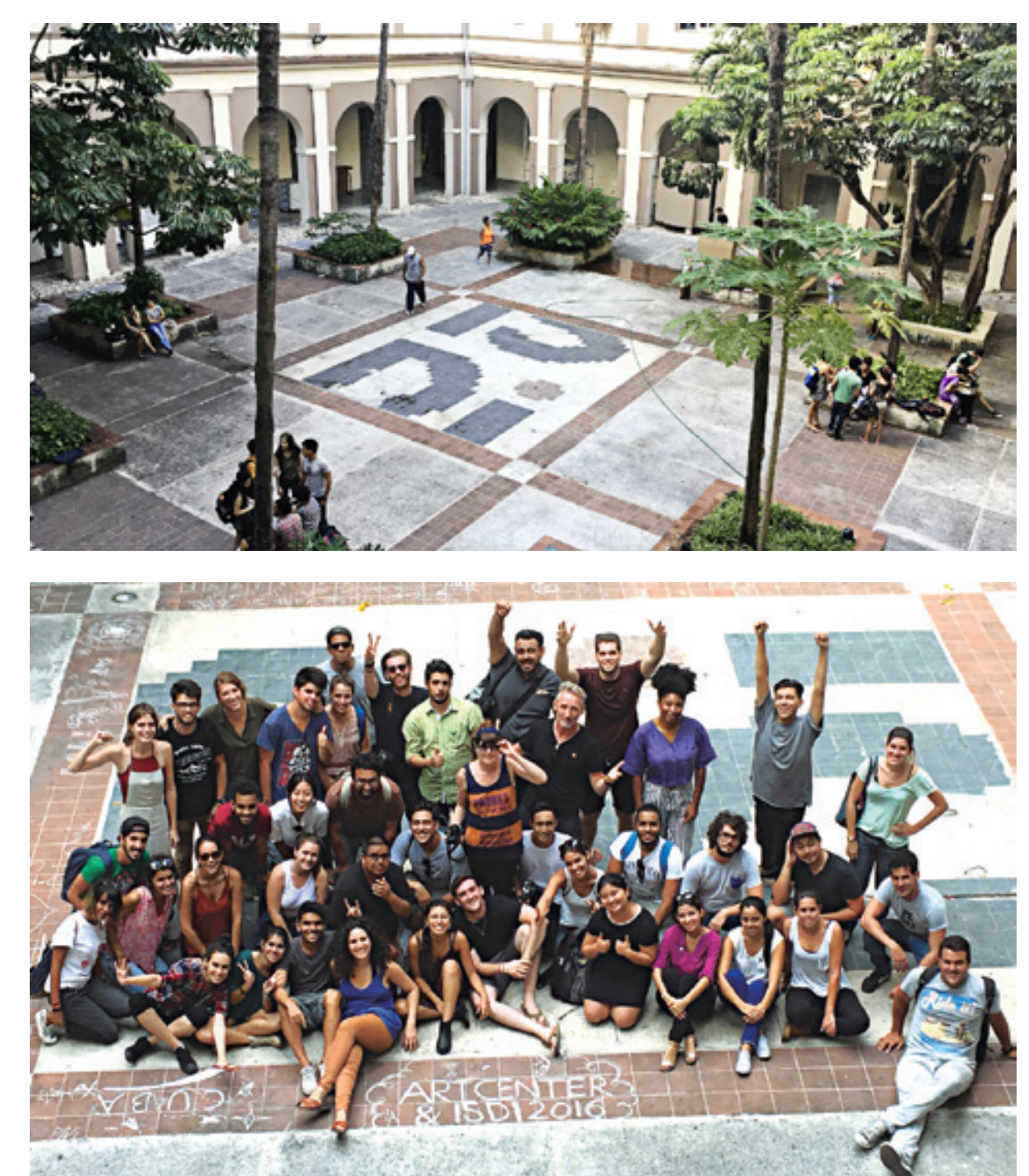

Fresh Eyes Cuba constituye una experiencia privilegiada de educación en diseño y que promueve el desarrollo de la conciencia social y política de los estudiantes.

Fresh Eyes Cuba is a privileged experience in design education and one that promotes the development of the students' social and political awareness. 


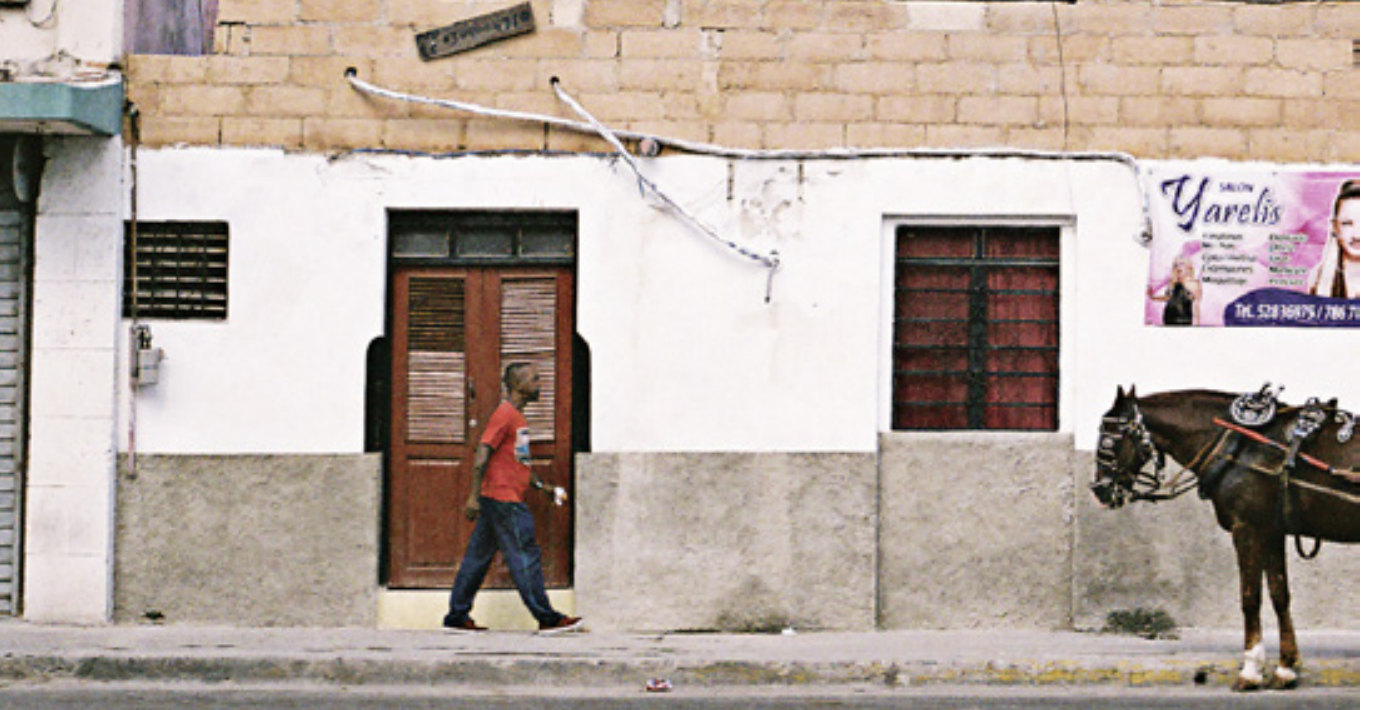

REFERENCES

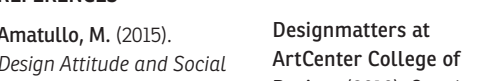

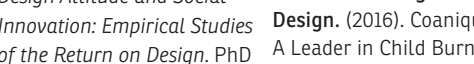
Dissertation, Case Western Care. In Designnatters

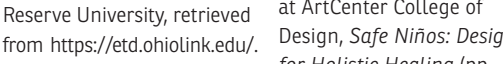

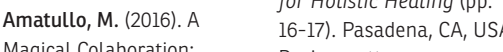
Magical Colaboration:
Harnesing the Power of Designmatters.

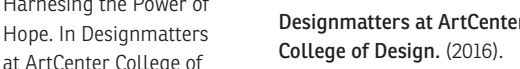
at Airtentere College of
Design, Safe Ninos: Design Safe Niños: Desigin for

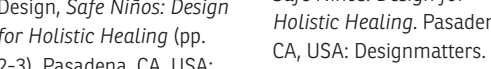

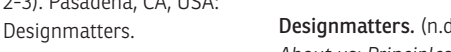

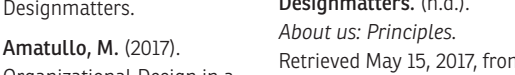

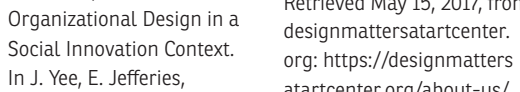

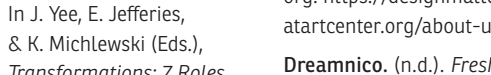

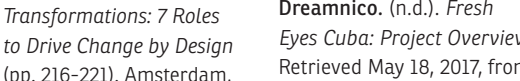

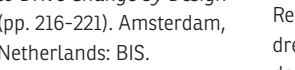

ArtCenter. (n d)

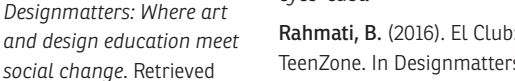

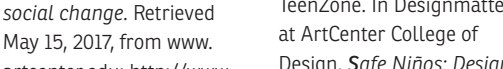

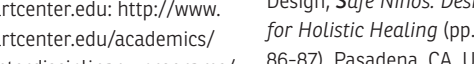

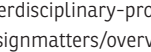

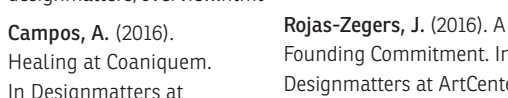
Designmatters.

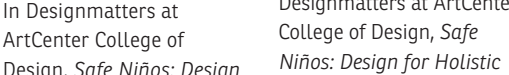

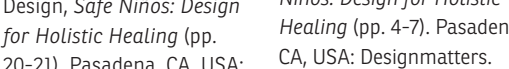

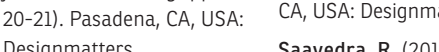
$\begin{array}{ll}\text { Designnaters. } & \text { Saavedra, } R \text {. (2016). } \\ \text { Coaniquem. (s.f.). Historia. Coaniquen: A Team }\end{array}$

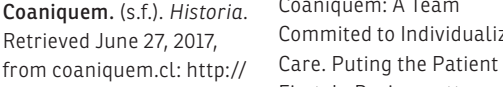

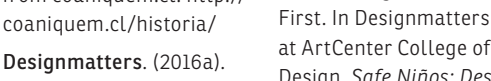
COANNQUEM: Safe Niños for Holistic Healing (pp.

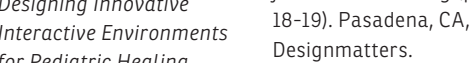
for Pediatric Healing.
Retriveved May 17, 2017, from Sternberg, E. (2016). The

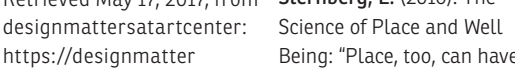

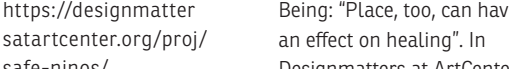

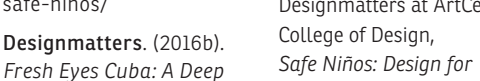

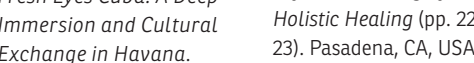

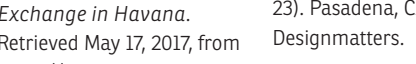
atartentererof(pori)

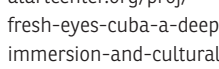

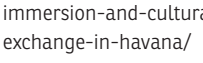

bonne. MA en Historia del Arte y Estudios Muse-

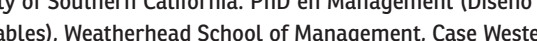
Reserve University. Es Co-Fundadora y Vice Presidenta de Designmatters

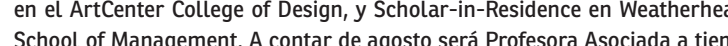
po completo en Parsons School of Design. Su investigación se centra en

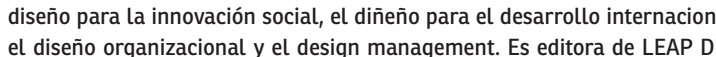

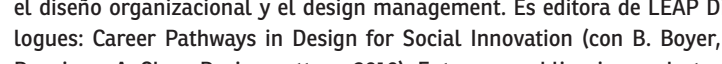

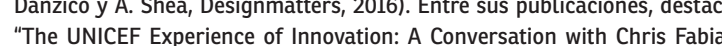
(en B. Ramalingam y K. Bound, Innovation in International Developmerte

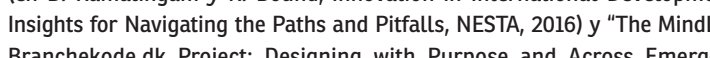

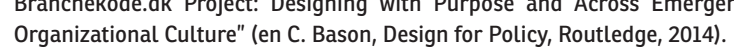

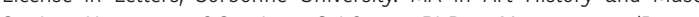

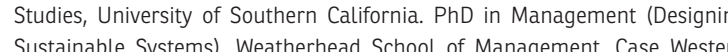
Reserve University. She is Co-Founder and Vice President of Designmatters (1) at Parsons School of Design. Her r research focusese in desiggn for socia

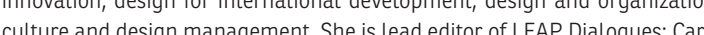
attwayys in Design for Social Innovation (with editiors B. Boyer, L. Danzico and

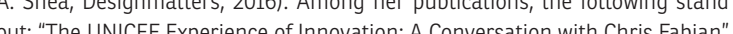
(in B. Ramalingam and K. Bound, Innovation in International Development Insights for Navigating the Paths and Prfitalls, NESTA, 2016) and "The MindL Organizational Culture" (in C. Bason, Design for P Policy, Routledge, 2014).

Licenciada en Estética en Artes Visuales, Pontificia Universidad Católica de Chile. Magister en Esteteticas Americanas, Pontificia Universidad Católicica de Chile

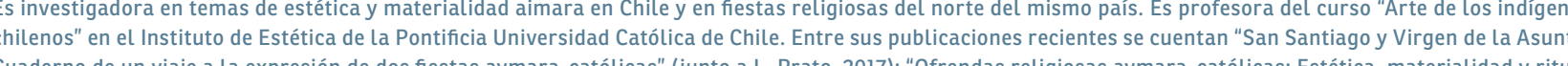

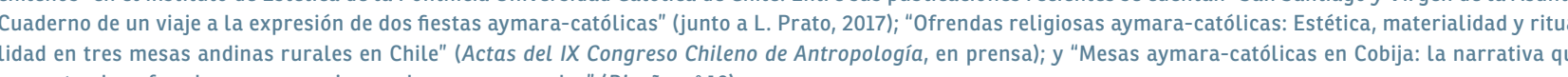

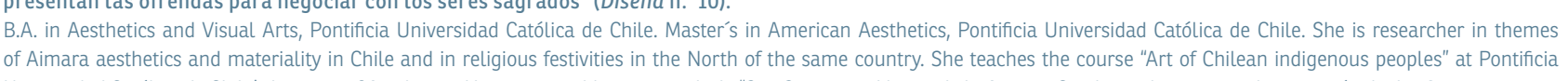

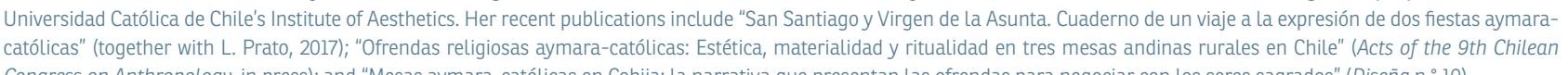
XIMENA ULIBARRI

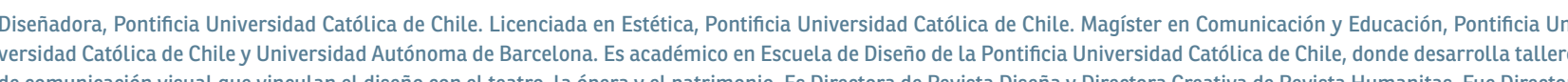

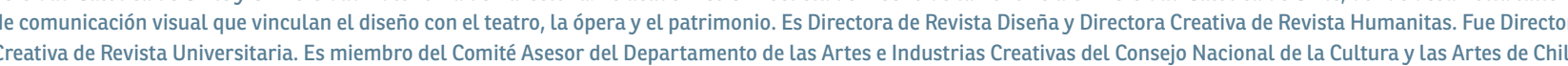

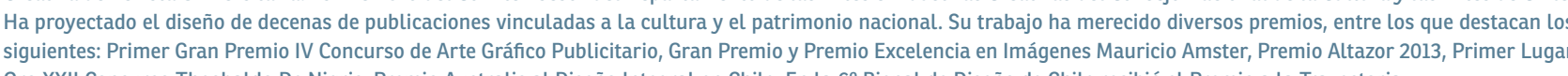

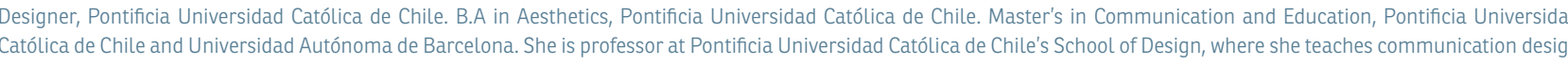

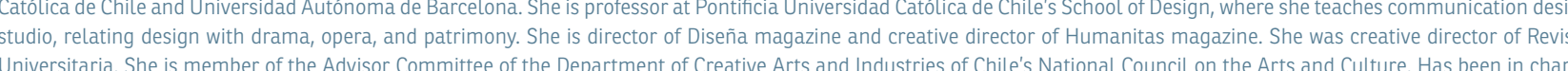

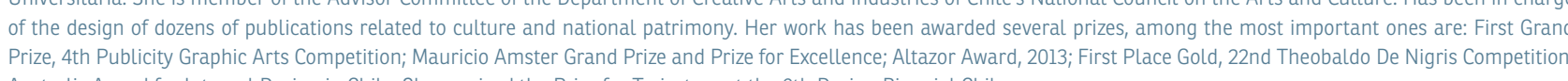
RENATO BERNASCON

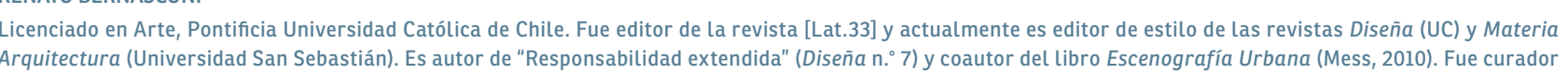

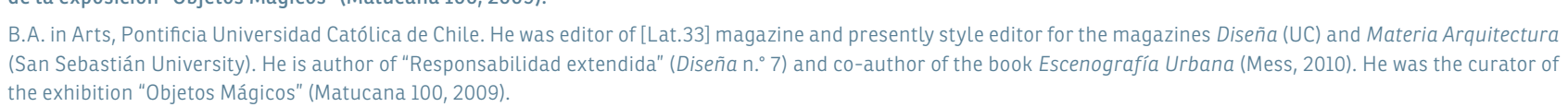

